\title{
PENGARUH JENIS PELARUT TERHADAP AKTIVITAS ANTIOKSIDAN EKSTRAK MENIRAN (Phyllanthus niruri L.)
}

\section{The Effect of Different Solvents on The Antioxidant Activity of Gale of The Wind Extract (Phyllanthus niruri L.)}

\author{
${ }^{1}$ Rizky Amalia Rachmawati, ${ }^{2} \mathrm{Ni}$ Wayan Wisaniyasa*, ${ }^{2}$ I Ketut Suter \\ ${ }^{1}$ Mahasiswa Program Studi Ilmu dan Teknologi Pangan, Fakultas Teknologi Pertanian, Unud \\ ${ }^{2}$ Dosen Program Studi Ilmu dan Teknologi Pangan, Fakultas Teknologi Pertanian, Unud \\ Kampus Bukit Jimbaran, Badung-Bali
}

\begin{abstract}
This study was conducted to determine the effect of different solvents on the antioxidant activity of gale of the wind extract and to find out the right type of solvent used to extract gale of the wind with the highest antioxidant activity using maceration method. The experimental design used in this study was a completely randomized design (CRD) with a type of solvent as a treatment. The treatment consisting of four levels, namely methanol, ethanol, acetone, isopropanol. All treatments were repeated four times so that they were obtained 16 experimental units. The data obtained were analyzed by variance and if the treatment had significant effect followed by Duncan test. The results showed that the type of solvent treatment had a very significant effect on yield, total phenol, total flavonoids, total tannin, and antioxidant activity $\left(\mathrm{IC}_{50}\right)$. The results showed that acetone solvent had the best treatment which produced a yield of $22.58 \%$, total phenol content of $188.77 \mathrm{mg} \mathrm{GAE} / \mathrm{g}$, total flavonoid content of $247.60 \mathrm{mg} \mathrm{QE} / \mathrm{g}$, total tannin content of $297.51 \mathrm{mg} \mathrm{TAE} / \mathrm{g}$, and antioxidant activity $\left(\mathrm{IC}_{50}\right)$ of $15.19 \mathrm{ppm}$.
\end{abstract}

Keywords: antioxidant activity, gale of the wind, maceration, solvent

\section{PENDAHULUAN}

Penggunaan antioksidan sintetis seperti BHA dan BHT dilarang di beberapa negara maju seperti Jepang dan Kanada sedangkan penggunaan BHA dan BHT di Indonesia masih diizinkan. Ayucitra et al. (2011) melaporkan bahwa antioksidan sintetis berpotensi menyebabkan kanker dalam tubuh. Polifenol dan flavonoid pada tanaman dapat menghambat radikal bebas sehingga menghambat kerusakan oksidatif (Ingrid dan Santoso, 2014). Oleh karena itu, senyawa golongan fenolik pada tanaman memiliki potensi menggantikan antioksidan sintetis pada produk pangan. Salah satu tanaman yang berpotensi sebagai sumber antioksidan adalah meniran (Febriana, 2015).

Tanaman meniran merupakan salah satu tumbuhan liar keluarga Euphorbiaceae yang hidup di iklim tropis. Di Indonesia meniran sangat mudah ditemukan di tepi jalan, kebun, tanah yang kosong, sungai, dan pekarangan rumah. Herba meniran mengandung senyawa golongan fenol, flavonoid, tanin, dan alkaloid (Sudarsono et al., 1996). Senyawa bioaktif tersebut dapat diperoleh dengan cara ekstraksi (Padmalochana dan Rajan, 2014). Metode ekstraksi yang digunakan pada penelitian ini adalah maserasi. Kelebihan metode maserasi dibandingkan metode ekstraksi lainnya adalah biayanya yang murah, mudah untuk dilakukan dan tanpa pemanasan sehingga tidak merusak senyawa flavonoid (Cuppet et al., 1954).

Selain metode ekstraksi, faktor yang dapat mempengaruhi hasil ekstraksi adalah jenis pelarut yang digunakan dalam ekstraksi (Sayuti, 2017). Pelarut yang digunakan disesuaikan dengan kepolaran senyawa yang

*Korespondensi penulis : 
ditargetkan. Menurut prinsip like dissolves like, suatu pelarut akan cenderung melarutkan senyawa yang mempunyai tingkat kepolaran yang sama. Pelarut polar akan melarutkan senyawa polar dan sebaliknya (Suryani et al., 2015). Senyawa flavonoid bersifat polar sehingga dibutuhkan pelarut yang bersifat polar (Gillespie dan Paul, 2011). Pelarut yang bersifat polar diantaranya adalah metanol, etanol, aseton (Sudarmadji et al., 1997), dan isopropanol (Moehady dan Djenar, 2018).

Karimi et al. (2014) melaporkan bahwa pelarut aseton 60\% mampu menghasilkan aktivitas antioksidan lebih tinggi dari aseton $20 \%, 40 \%, 80 \%, 100 \%$ dan aquades pada ekstrak daun oregano mediterania, sedangkan Kiritsakis et al. (2010) menyatakan bahwa pelarut metanol $60 \%$ menghasilkan aktivitas antioksidan tertinggi pada ekstrak daun zaitun dibandingkan metanol absolut, petroleum eter (PE), dan diklorometan. Herrero et al. (2005) juga menyatakan pelarut isopropanol $60 \%$ menghasilkan aktivitas antioksidan daun rosmarin lebih baik daripada isopropanol $80 \%$. Sementara itu, Martinus dan Rivai (2011) melaporkan bahwa pelarut etanol 60\% mampu menghasilkan aktivitas antioksidan ekstrak meniran tertinggi dibandingkan pelarut etanol 50\%, 70\%, 80\%, dan 100\%. Penelitian tersebut belum membandingkan jenis pelarut apa yang optimal untuk mendapatkan senyawa antioksidan pada meniran. Setiap komponen pembentuk bahan mempunyai jumlah dan komponen dengan kelarutan yang beragam sehingga penggunaan pelarut dengan tingkat kepolaran yang berbeda akan menghasilkan komponen terekstraksi yang berbeda-beda
(Chandra dan Novalia, 2014). Oleh karena itu perlu dilakukan penelitian untuk menentukan jenis pelarut yang paling tepat sehingga diperoleh ekstrak meniran dengan aktivitas antioksidan tertinggi.

\section{METODE PENELITIAN}

\section{Tempat dan Waktu}

Penelitian ini dilaksanakan di Laboratorium Pengolahan Pangan, Laboratorium Analisis Pangan, dan Laboratorium Biokimia dan Nutrisi, Fakultas Teknologi Pertanian Universitas Udayana. Penelitian ini dilakukan pada bulan Agustus Oktober 2019.

\section{Bahan dan Alat}

Bahan yang digunakan dalam penelitian ini adalah meniran berumur 2 bulan yang diperoleh dari areal kebun Jl. Raya Puputan, Kecamatan Denpasar Timur, Kota Denpasar, Bali dan bahan-bahan kimia seperti 2,2-diphenyl-1-picryl-hydrazyl

(DPPH) (Himedia), Folin-Ciocalteu (Merck), FolinDenis (Merck), etanol (Merck), akuades, metanol (Merck), aseton (Merck), isopropanol (Merck), asam galat (Merck), $\mathrm{Na}_{2} \mathrm{CO}_{3}$ (Merck), $\mathrm{AlCl}_{3}$ (Merck), $\mathrm{NaNO}_{2}$ (Merck), $\mathrm{NaOH}$ (Merck), asam tanat (Merck), dan kuersetin (Sigma Aldrich).

Peralatan yang digunakan dalam penelitian ini yaitu oven (Labo DO 225), blender (Philips), timbangan analitik (Sartorius), ayakan 60 mesh (Retsch), rotary vakum evaporator (IKA Labortechnik), spektrofotometer UV-VIS (Genesys $10 S \mathrm{UV}$ Vis), erlenmeyer (Pyrex), tabung reaksi 
(Pyrex), vortex (Mix Max II), aluminium foil, kertas saring Whatman No. 1, dan alat-alat gelas.

\section{Rancangan Percobaan}

Rancangan yang digunakan pada penelitian ini adalah Rancangan Acak Lengkap (RAL) yang terdiri dari 4 perlakuan jenis pelarut dan 4 kali ulangan sehingga diperoleh 16 unit percobaan. Perlakuan ekstraksi meniran dengan perbedaan pelarut yaitu: P1 (Metanol 60\%), P2 (Etanol 60\%), P3 (Aseton 60\%), P4 (Isopropanol 60\%). Data yang diperoleh dianalisis dengan sidik ragam, apabila perlakuan berpengaruh, maka dilanjutkan dengan uji Duncan (Steel dan Torrie, 1993).

\section{Pelaksanaan Penelitian}

\section{Persiapan Bahan Baku}

Persiapan sampel dimulai dengan sortasi meniran. Selanjutnya, meniran dicuci menggunakan air mengalir dan ditiriskan. Dilakukan pengeringan menggunakan oven dengan suhu $40^{\circ} \mathrm{C}$ selama 12 jam. Selanjutnya dilakukan penghancuran menjadi bubuk menggunakan blender. Tahap berikutnya yaitu mengayak hasil meniran yang telah menjadi bubuk mengunakan ayakan 60 mesh.

\section{Ekstraksi Bubuk Meniran}

Bubuk meniran diekstrak menggunakan metode maserasi. Sebanyak 10 gram bubuk dilarutkan dengan $100 \mathrm{ml}$ pelarut sesuai perlakuan (metanol 60\%, etanol 60\%, aseton $60 \%$, isopropanol 60\%) kemudian dimaserasi selama 30 jam pada suhu kamar. Larutan disaring dengan kertas saring Whatman no.1.
Filtrat kemudian dipekatkan menggunakan rotary vakum evaporator pada suhu $40^{\circ} \mathrm{C}$ (Martinus dan Rivai, 2011). Ekstrak meniran kemudian dianalisis rendemen, total fenol, total flavonoid, total tanin, aktivitas antioksidan $\left(\mathrm{IC}_{50}\right)$.

\section{HASIL DAN PEMBAHASAN}

Hasil analisis rendemen, total fenol, total flavonoid, total tanin, dan aktivitas antioksidan $\left(\mathrm{IC}_{50}\right)$ dari ekstrak meniran dapat dilihat pada Tabel 1.

\section{Rendemen}

Hasil sidik ragam menunjukkan bahwa jenis pelarut berpengaruh sangat nyata $(\mathrm{P}<0,01)$ terhadap rendemen ekstrak meniran.

Tabel 1 menunjukkan bahwa pelarut aseton menghasilkan rendemen ekstrak meniran tertinggi yaitu $22,58 \% \pm 0,79$ sedangkan pelarut isopropanol menghasilkan rendemen terendah yaitu $17,14 \% \pm 0,88$.

Tingginya rendemen ekstrak meniran dengan pelarut aseton berhubungan dengan kepolaran pelarut dan kepolaran senyawa yang diekstraksi. Hal ini menunjukan bahwa kepolaran senyawa-senyawa yang terdapat pada ekstrak meniran memiliki kepolaran yang relatif sama dengan kepolaran aseton. Hal ini sesuai dengan prinsip "like dissolves like" perolehan senyawa kimia didasarkan pada kesamaan sifat kepolaran terhadap pelarut yang digunakan. Menurut Fatiha et al. (2012), jenis dan polaritas pelarut sangat mempengaruhi rendemen yang dihasilkan. Stankovic et al. (2012) menyatakan bahwa tanaman mengandung senyawa fenolik yang bervariasi dari yang sederhana hingga 
terpolimerisasi dalam jumlah yang berbeda.

Polaritas pelarut berperan penting dalam peningkatan kelarutan senyawa fenolik. Hal ini sesuai dengan penelitian Do et al. (2014) yang menyatakan bahwa pelarut aseton menghasilkan rendemen ekstrak Limnophila aromatica tertinggi dibandingkan metanol dan etanol. Suryani et al. (2015) menyatakan bahwa pelarut aseton menghasilkan rendemen ekstrak daun matoa lebih tinggi dibandingkan pelarut isopropanol.

Tabel 1. Nilai rata-rata rendemen, total fenol, total flavonoid, total tanin, dan aktivitas antioksidan $\left(\mathrm{IC}_{50}\right)$ dari ekstrak meniran.

\begin{tabular}{cccccc}
\hline $\begin{array}{c}\text { Jenis } \\
\text { Pelarut }\end{array}$ & $\begin{array}{c}\text { Rendemen } \\
(\%)\end{array}$ & $\begin{array}{c}\text { Total Fenol } \\
(\mathrm{mg} \text { GAE/g })\end{array}$ & $\begin{array}{c}\text { Total Flavonoid } \\
(\mathrm{mg} \text { QE/g })\end{array}$ & $\begin{array}{c}\text { Total Tanin } \\
(\mathrm{mg} \text { TAE/g })\end{array}$ & $\begin{array}{c}\text { Aktivitas } \\
\text { Antioksidan } \\
(\%)\end{array}$ \\
\hline $\begin{array}{c}\text { Metanol } \\
60 \%\end{array}$ & $18,68 \pm 0,84^{\mathrm{c}}$ & $113,12 \pm 0,83^{\mathrm{d}}$ & $209,05 \pm 0,75^{\mathrm{d}}$ & $222,70 \pm 0,70^{\mathrm{d}}$ & $49,11 \pm 0,41^{\mathrm{d}}$ \\
$\begin{array}{c}\text { Etanol } \\
60 \%\end{array}$ & $21,07 \pm 1,03^{\mathrm{b}}$ & $174,11 \pm 1,18^{\mathrm{b}}$ & $269,26 \pm 1,21^{\mathrm{a}}$ & $286,63 \pm 1,12^{\mathrm{b}}$ & $65,22 \pm 0,31^{\mathrm{b}}$ \\
$\begin{array}{c}\text { Aseton } \\
60 \%\end{array}$ & $22,58 \pm 0,79^{\mathrm{a}}$ & $188,77 \pm 1,05^{\mathrm{a}}$ & $247,60 \pm 1,23^{\mathrm{b}}$ & $297,51 \pm 1,20^{\mathrm{a}}$ & $71,99 \pm 0,42^{\mathrm{a}}$ \\
$\begin{array}{c}\text { Isopropa } \\
\text { nol 60\% }\end{array}$ & $17,14 \pm 0,88^{\mathrm{c}}$ & $149,18 \pm 0,63^{\mathrm{c}}$ & $212,70 \pm 1,14^{\mathrm{c}}$ & $266,19 \pm 0,96^{\mathrm{c}}$ & $58,08 \pm 0,55^{\mathrm{c}}$ \\
\hline
\end{tabular}

Keterangan: Huruf yang sama dibelakang nilai rata-rata pada kolom yang sama menunjukkan berbeda tidak nyata $(\mathrm{P}<0,05)$.

Sebaliknya, pelarut isopropanol menghasilkan rendemen ekstrak meniran terendah. Hal ini disebabkan karena pelarut isopropanol memiliki konstanta dielektrik terendah. Menurut Yohed dan Kristiannita (2017) konstanta dielektrik merupakan ukuran kepolaran suatu pelarut. Semakin tinggi konstanta dielektrik pelarut, semakin polar pelarut tersebut begitu pula sebaliknya. Hal tersebut mempengaruhi kemampuan pelarut dalam ekstraksi sehingga penggunaan pelarut yang berbeda menghasilkan rendemen yang berbeda, bergantung pada polaritasnya. Konstanta dielektrik metanol, etanol, aseton, dan isopropanol berturur-turut yaitu 32, 24, 21, 18 (Sudarmadji et al., 1997). Oleh karena itu, ekstrak meniran yang menggunakan pelarut isopropanol menghasilkan rendemen terendah.

\section{Total Fenol}

Hasil sidik ragam menunjukkan bahwa jenis pelarut berpengaruh sangat nyata $(\mathrm{P}<0,01)$ terhadap total fenol ekstrak meniran. Tabel 1 menunjukkan bahwa total fenol tertinggi terdapat pada jenis pelarut aseton yaitu $188,77 \pm 1,05 \mathrm{mg}$ GAE/g. Total fenol terendah terdapat pada jenis pelarut metanol yaitu $113,12 \pm 0,83 \mathrm{mg} \mathrm{GAE} / \mathrm{g}$.

Hasil penelitian ini menunjukkan bahwa aseton efektif digunakan untuk mengekstrak meniran sehingga menghasilkan total fenol tertinggi. Hal tersebut menunjukkan bahwa kepolaran senyawa fenolik ekstrak meniran sesuai dengan kepolaran aseton. Senyawa yang diperoleh dari ekstraksi didasarkan pada kesamaan sifat kepolaran terhadap pelarut yang digunakan (Harborne, 
1996). Senyawa fenolik merupakan senyawa yang memiliki satu atau lebih gugus hidroksil yang berikatan dengan gugus aromatik. Menurut Nur dan Astawan (2011) senyawa fenolik memiliki sifat kepolaran yang luas. Septiana dan Asnaini (2012) menyatakan bahwa kelarutan senyawa fenolik tidak selalu terdapat pada pelarut dengan kepolaran tinggi karena senyawa fenolik terdiri dari molekulmolekul dengan beragam struktur sehingga mempengaruhi kelarutannya. Pada penelitian ini total fenol tertinggi terdapat pada ekstrak meniran yang menggunakan pelarut aseton. Aseton merupakan pelarut polar yang memiliki gugus fungsi keton $(\mathrm{C}=\mathrm{O})$. Adanya atom $\mathrm{O}$ pada gugus keton pada aseton dapat membentuk ikatan hidrogen dengan atom $\mathrm{H}$ dari gugus hidroksil senyawa fenolik (Rachmawati et al., 2018). Hal ini sesuai dengan penelitian Sepahpour et al. (2018) bahwa pelarut aseton menghasilkan total fenol tertinggi pada sereh dibandingkan metanol dan etanol. Venkatesan et al. (2019) menyatakan pelarut aseton menghasilkam total fenol lebih tinggi pada $P$. densiflora dibandingkan dengan pelarut isopropanol.

Total fenol terendah terdapat pada perlakuan pelarut metanol. Menurut Neswadi dan Isyanto (2018) penggunaan pelarut dengan tingkat kepolaran yang terlalu tinggi dapat melarutkan senyawa-senyawa lain seperti gula, air, dan protein larut air sehingga kadar senyawa fenol dalam suatu ekstrak menjadi rendah.

\section{Total Flavonoid}

Hasil sidik ragam menunjukkan bahwa perlakuan jenis pelarut berpengaruh sangat nyata $(\mathrm{P}<0,01)$ terhadap total flavonoid ekstrak meniran. Tabel 1 menunjukkan bahwa total flavonoid tertinggi diperoleh dengan menggunakan pelarut etanol yaitu 269,26 $\pm 1,21$ $\mathrm{mg}$ QE/g dan total flavonoid terendah diperoleh menggunakan pelarut metanol yaitu 209,05 $\pm 0,75 \mathrm{mg} \mathrm{QE} / \mathrm{g}$.

Total flavonoid tertinggi pada ekstrak meniran menggunakan pelarut etanol menunjukkan bahwa pelarut etanol memiliki tingkat kepolaran yang menyerupai senyawa flavonoid. Hal ini diduga senyawa flavonoid yang terdapat dalam meniran berikatan dengan gula. Menurut Cuppett et al. (1954) flavonoid dalam tanaman dapat berikatan dengan gula (dalam bentuk glikosida) atau dalam bentuk bebas (aglikon). Namun, sebagian besar flavonoid ditemukan dalam bentuk glikosida. Adanya gula yang terikat pada flavonoid cenderung menyebabkan flavonoid lebih mudah larut pada pelarut polar (Suryani et al., 2015). Menurut Harborne (1996) senyawa flavonoid terbagi menjadi beberapa jenis, tiap jenis flavonoid mempunyai kepolaran yang berbeda-beda tergantung dari jumlah dan posisi gugus hidroksil tiap jenis flavonoid sehingga hal tersebut akan mempengaruhi kelarutan flavonoid pada pelarut. Pelarut etanol merupakan pelarut polar dengan konstanta dielektrik yaitu 24,60. Suatu senyawa akan larut pada pelarut yang mempunyai kepolaran yang sama (Harborne, 1996). Hal ini sesuai dengan penelitian Sepahpour et al. (2018) bahwa pelarut etanol 
menghasilkan total flavonoid paling tinggi dibandingkan pelarut metanol dan aseton pada daun kari. Selain itu, El-Malah et al. (2015) melaporkan pelarut etanol menghasilkan total flavonoid lebih tinggi dibandingkan pelarut isopropanol pada tomat.

Total flavonoid terendah terdapat pada perlakuan pelarut metanol. Septiana dan Asnaini (2012) menyatakan bahwa penggunaan pelarut dengan tingkat kepolaran yang tinggi dapat melarutkan komponen yang bersifat polar seperti karbohidrat ikut terekstrak dan menyebabkan total flavonoid per berat sampel menjadi rendah.

\section{Total Tanin}

Hasil sidik ragam menunjukkan bahwa jenis pelarut berpengaruh sangat nyata $(\mathrm{P}<0,01)$ terhadap total tanin ekstrak meniran.

Tabel 1 menunjukkan bahwa total tanin tertinggi diperoleh pada pelarut aseton yaitu 297,51 $\pm 1,20 \mathrm{mg}$ TAE/g sedangkan total tanin terendah diperoleh pada pelarut metanol yaitu $222,70 \pm 0,70 \mathrm{mg}$ TAE/g.

Tingginya total tanin pada pelarut aseton menunjukkan bahwa kepolaran senyawa tanin pada ekstrak meniran menyerupai dengan kepolaran aseton. Hal ini juga dapat disebabkan aseton dapat mendegradasi ikatan kompleks dengan protein pada proses ekstraksi sehingga kadar tanin yang dihasilkan lebih tinggi (Sepahpour et al., 2018). Hwang dan Thi (2014) juga melaporkan bahwa aseton dapat memutus ikatan hidrogen antara gugus hidroksil fenol dan gugus karboksil protein pada ikatan kompleks dengan protein. Harborne (1996) menyatakan bahwa di dalam tumbuhan letak tanin terpisah dari protein dan enzim. Jika jaringan rusak maka tanin terbebaskan dan membentuk ikatan kompleks dengan protein. Oleh karena itu, ekstrak meniran yang menggunakan pelarut aseton menghasilkan total tanin yang lebih tinggi. Hal ini sesuai dengan penelitian Sepahpour et al. (2018) menyatakan bahwa pelarut aseton menghasilkan total fenolik tertinggi pada sereh, jahe, dan kunyit dibandingkan metanol dan etanol. Hal ini sesuai dengan penelitian Mokrani dan Madani (2016) melaporkan bahwa pelarut aseton menghasilkan total tanin pada ekstrak buah persik tertinggi dibandingkan metanol dan etanol.

Total tanin terendah terdapat pada ekstrak yang menggunakan pelarut metanol. Menurut Fahey dan Berger (1988) tanin merupakan senyawa fenolik yang memiliki berat molekul tinggi. Do et al. (2014) melaporkan bahwa metanol lebih efektif dalam mengekstrak senyawa yang memiliki berat molekul rendah. Hal tersebut mengakibatkan total tanin pada ekstrak meniran yang menggunakan metanol paling rendah dibandingkan pelarut lain.

\section{Aktivitas Antioksidan $\left(\mathrm{IC}_{50}\right)$}

Hasil sidik ragam menunjukkan bahwa jenis pelarut berpengaruh sangat nyata $(\mathrm{P}<0,01)$ terhadap aktivitas antioksidan ekstrak meniran. Tabel 1 menunjukkan bahwa aktivitas antioksidan tertinggi diperoleh pada pelarut aseton yaitu $71,99 \% \pm 0,42$ sedangkan aktivitas antioksidan terendah diperoleh pada pelarut metanol yaitu $49,11 \% \pm 0,41$. Hal ini 
menunjukkan pelarut aseton efektif dalam mengekstrak senyawa antioksidan meniran. Hal ini sesuai dengan penelitian Suryani et al. (2015) yang melaporkan bahwa aseton menunjukkan aktivitas antioksidan ekstrak daun matoa tertinggi dibandingkan pelarut aquades, metanol, etanol, dan isopropanol.

Adanya hidrogen bebas menyebabkan senyawa fenolik memiliki aktivitas antioksidan sehingga semakin tinggi total fenolnya maka semakin tinggi juga aktivitas antioksidannya. Berdasarkan hasil analisis aktivitas antioksidan, pelarut aseton memiliki persentase aktivitas antioksidan tertinggi sehingga perlakuan ini dipilih untuk diuji penentuan $\mathrm{IC}_{50}$. Berdasarkan analisis regresi linier diperoleh persamaan yaitu $\mathrm{y}=2,9952 \mathrm{x}$ 4,5015 sehingga didapat nilai $\mathrm{IC}_{50}$ sebesar 15,19 ppm. IC IC $_{50}$ menggambarkan besarnya konsentrasi suatu senyawa yang mampu menghambat radikal bebas (DPPH) sebanyak 50\%. Menurut Blois (1958) suatu senyawa memiliki antioksidan sangat kuat apabila nilai $\mathrm{IC}_{50}$ kurang dari $50 \mathrm{ppm}$. Oleh karena itu, nilai $\mathrm{IC}_{50}$ pada ekstrak meniran tergolong sangat kuat.

\section{KESIMPULAN DAN SARAN}

\section{Kesimpulan}

Berdasarkan hasil dan pembahasan penelitian maka dapat disimpulkan sebagai berikut.

1. Jenis pelarut berpengaruh sangat nyata terhadap rendemen, total fenol, total flavonoid, total tanin, dan aktivitas antioksidan ekstrak meniran.
2. Pelarut terbaik untuk mengekstrak meniran adalah pelarut aseton $60 \%$ dengan karakteristik rendemen sebesar $22,58 \%$, total fenol sebesar $188,77 \mathrm{mg}$ $\mathrm{GAE} / \mathrm{g}$, total flavonoid sebesar 247,60 $\mathrm{mg}$ QE/g, total tanin sebesar 297,51 mg $\mathrm{TAE} / \mathrm{g}$, dan aktivitas antioksidan berdasarkan $\mathrm{IC}_{50}$ sebesar 15,19 ppm.

\section{Saran}

1. Berdasarkan hasil penelitian ini disarankan menggunakan pelarut aseton $60 \%$ untuk mengekstrak meniran.

2. Perlu dilakukan penelitian mengenai enkapsulasi ekstrak meniran sehingga ekstrak meniran lebih stabil untuk digunakan.

\section{DAFTAR PUSTAKA}

Anonimous. 1995. Official Methods of Analysis. Association of Official Analytical Chemists, Washington.

Ayucitra, A., N. Indraswati, V. Mulyandasari, Y. K. Dengi, F. Francisco, dan A. Yudha. 2011. Potensi senyawa fenolik bahan alam sebagai antioksidan alami minyak goreng nabati. Jurnal Teknik Kimia. 10(1): 1-10.

Blois, M. S. 1958. Antioxidant determinations by the use of a stable free radical. Nature. 181: 1199-1200.

Chandra, A., dan N. Novalia. 2014. Studi awal ekstraksi batch daun stevia dengan variabel jenis pelarut dan temperatur. Jurnal of Science Engineering. 2:1-5.

Cuppett, S., M. Scnepf and C. Hall III. 1954. Natural Antioxidants - Are They A Reality. AOCS Press, Illinois.

Do, Q. D., A. E. Angkawijaya, P. L. TranNguyen, L. H. Huynh, F. E. Soetaredjo, and S. Ismadji. 2014. Effect of extraction solvent on total phenol content, total flavonoid content, and 
antioxidant activity of Limnophila aromatica. Journal of Food and Drug Analysis. 22(14) : 296 - 302 .

El-Malah, M. H., M. M. M. Hassanein, M. H. Areif, and E. F. Al-Amrousi. 2015. Utilization of egyptian tomato waste as a potential source of natural antioxidants using solvents, microwave and ultrasound extraction methods. Journal of Food Technology. 10(1): 14-25.

Fahey, G. C., and L.L. Berger. 1988. Carbohydrate nutrition of ruminants. In: The ruminant animal digestive physiology and nutrition. Prentice Hall. 5: 269-295.

Fatiha, B., M. Khodir, D. Farid, R. Tiziri, B. Karima, O. Sonia, and Mohamed, C. 2012. Optimisation of solvent extraction of antioxidants (phenolic compounds) from Algerian mint (Mentha spicata L.). Pharmacognosy Communications. 2: 72-86.

Febriana, M. V. 2015. Pengaruh meniran terhadap gambaran histopatologi hepar tikus putih jantan yang diinduksi obat anti tuberkulosis. Skripsi. Tidak dipublikasikan. Universitas Airlangga, Surabaya.

Garcia, C.A., P. Hevia and V.C. Gravino. 2007. Correlation of tocopherol, tokotrienol and total polyphenol content in rice bran with different antioxidant capacity assays. Journal of Food Chemistry. 102(4):1228-1232.

Gillipsie and R.J. Paul. 2001. Chemical Bonding and Molecular Geometry. Oxford University Press, London.

Harborne, J. B. 1996. Metode Fitokimia: Penuntun Cara Modern Menganalisis Tumbuhan. Penerbit ITB Press, Bandung.

Herrero, M., D. A. Roman, A. Segura, E. Kenndler, B. Gius, M. A. Raggi, E. Ibanez and A. Cifuentes. 2005. Pressurized liquid extraction-capillary electrophoresis-mass spectrometry for the analysis of polar antioxidants in rosemary extracts. Journal of Chromatoghraphy A. 1084(1): 54-62.
Huliselan, Y. M., M. R. J. Runtuwene, dan D. S. Wewengkang. 2015. Aktivitas antioksidan ekstrak etanol, etil asetat, dan n-heksan dari daun sesewanua. Journal Pharmacon. 4(3): 155-163.

Hwang, E.S., and N. D. Thi. 2014. Effects of extraction and processing methods on antioxidant compound contents and radical scavenging activities of laver (Porphyra tenera). Journal of Food Sci. (19): 40-48.

Inggrid, H. M. dan H. Santoso. 2014. Ekstraksi antioksidan dan senyawa aktif dari buah kiwi. Lembaga Penelitian dan Pengabdian Kepada Masyarakat. Tesis. Tidak dipublikasikan. Universitas Katolik Parahyangan, Bandung.

Karimi, A., B. Min, C. Brownmiller and S. O. Lee. 2014. Effects of extraction techniques on total phenolic content and antioxidant capacities of two oregano leaves. Journal of Food Research. 4(1): 112-123.

Kiritsakis, K., M. G. Kontominas, C. Kontogioris, D. Hadjipavlou-Litina, A. Moustaka and A. Kiritsakis. 2010. Composition and antioxidant activity of olive leaf extracts from Greek olive cultivars. J. Am. Oil. Chem. Soc. 87(4): 369-376.

Martinus, B. A., dan H. Rivai. 2011. Pengaruh perbandingan etanol:air sebagai pelarut ekstraksi terhadap perolehan kadar fenolat dan daya antioksidan herba meniran (Phyllanthus niruri L.). Jurnal Scientia. 1(1): 59-64.

Moehady, B. I. dan N. S. Djenar. 2018. Pengaruh komposisi media pertumbuhan terhadap produksi scleroglucan pada fermentasi aerob Sclerotium rolfsii Ina CC F-05. Jurnal Rekayasa Hijau. 3(2): 237-246.

Mokrani, A., and K. Madani. 2016. Effect of solvent, time, and temperature on the extraction of phenolics sompounds and antioxidant capacity of peach fruit. Separation and Purification Technology. 162: 68-76.

Nur, A. M., dan Astawan, M., 2011, Kapasitas antioksidan bawang dayak (Eleutherine palmifolia) dalam bentuk segar, simplisa 
dan keripik, pada pelarut nonpolar, Semipolar, dan polar. Skripsi. Tidak dipublikasikan. Departemen Ilmu dan Teknologi Pangan IPB, Bogor.

Padmalochana, K., and M. S. D. Rajan. 2014. Antimicrobial activity of aqueous, ethanol and acetone extracts of Sesbania grandiflora leaves and its phytochemical characterization. International Journal of Pharma Sciences and Research. 5(12):957-962.

Rachmawati, A. Munisa, Hasri, H. Pagarra, Hartati, dan Z. Maulana. 2013. Ekstraksi senyawa aktif dari kakao dan potensialnya sebagai fungisida. Jurnal of Physics. 1028(1):012013.

Rafi, M., N. Widyastuti, E. Suradikusumah dan L. K. Darusman. 2012. Aktivitas antioksidan, kadar fenol, dan flavonoid total dari enam tumbuhan obat Indonesia. Jurnal Bahan Alam Indonesia. 8(3):159-165.

Rajan, S., S. Mahalakhsmi, V. M. Deepa, K. Sathya, S. Shajitha, and T. Thirunalasundhari. 2012. Antioxidant potentials of Punica granatum fruit rind extracts. International Journal of Pharmacy and Pharmaceutical Sciences. 3(3): 82-88.

Sarwono, J. 2006. Metode Penelitian Kuantitatif dan Kualitatif. Penerbit: Graha Ilmu, Yogyakarta.

Sayuti, M. 2017. Pengaruh perbedaan metode ekstraksi, bagian dan jenis pelarut terhadap rendemen dan aktifitas antioksidan bambu laut (Isis hippuris). Technology Science and Engineering Journal. 1(3): 166-174.

Sepahpour, S., J. Selamat, M. Y. A. Manap, A. Khatib and A. F. A. Razis. 2018. Comparative analysis of chemical composition, antioxidant activity and quantitative characterization of some phenolic compounds in selected herbs and spices in different solvent extraction systems. 23(2): 402-419.

Septian, A.T., dan A. Asnani. 2012. Kajian sifat fisikokimia ekstrak rumput laut coklat Sargassum duplicatum menggunakan berbagai pelarut dan metode ekstraksi. Agrointek. 6(1): 22 28.

Shah, P and H. A. Modi. 2015. Comparative study of DPPH, ABTS and FRAP assay for determination antioxidant activity. International Journal for Reasearch in Applied Scince and Engineering Technology. 3(4):636-641.

Singh, R., P. K. Verma and G. Singh. 2012. Total phenolic, flavonoids and tannin contents in different extracts of Artemisia absinthium. Journal of Intercultural Ethnopharmacology. 1(2):101-104.

Stankovic, M.S., N. Niciforovic, V. Mihailovic, M. Topuzovic, and S. Solujic. 2012. Antioxidant activity, total phenolic content and flavonoid concentrations of different plant parts of Teucrium polium L. subsp. polium. Acta Societatis Botanicorum Poloniae. 81: 117-122.

Steel, R.G.D. and J. H. Torrie. 1993. Prinsip dan Prosedur Statistika Suatu Pendekatan Biometrik. Gramedia Pustaka Utama, Jakarta.

Sudarmadji, S., B. Haryono dan Suharji. 1997. Prosedur Analisis Untuk Bahan Makanan Dan Pertanian. Penerbit Liberti, Yogyakarta.

Sudarsono, A., P. Afus dan D. Gunawan. 1996. Phyllanthus niruri L. (Euphorbiaceae) Dalam Tumbuhan Obat. Penerbit Agromedia Pustaka, Jakarta.

Suryani, N. C., D. G. M. Permana, dan A. A. G. N. A. Jambe. 2015. Pengaruh jenis pelarut terhadap kandungan total flavonoid dan aktivitas antioksidan ekstrak daun matoa (Pometia pinnata). Jurnal Ilmu dan Teknologi Pangan. 5(1): 1-10.

Venkatesan, T., Y. W. Choi, and Y. K. Kim. 2019. Impact of different extraction solvents on phenolic content and antioxidant potential of $P$. densiflora bark extract. BioMed Reasearch International. 19: 2-14.

Yohed, I. dan R. A. Kristianita. 2017. Pengaruh jenis pelarut dan temperatur 
terhadap flavonoid content dan aktivitas antioksidan ekstrak daun nyamplung. Skripsi. Tidak dipublikasikan. Departemen Teknik Kimia Fakultas Teknologi Industri Institut Teknologi Sepuluh Nopember, Surabaya. 